
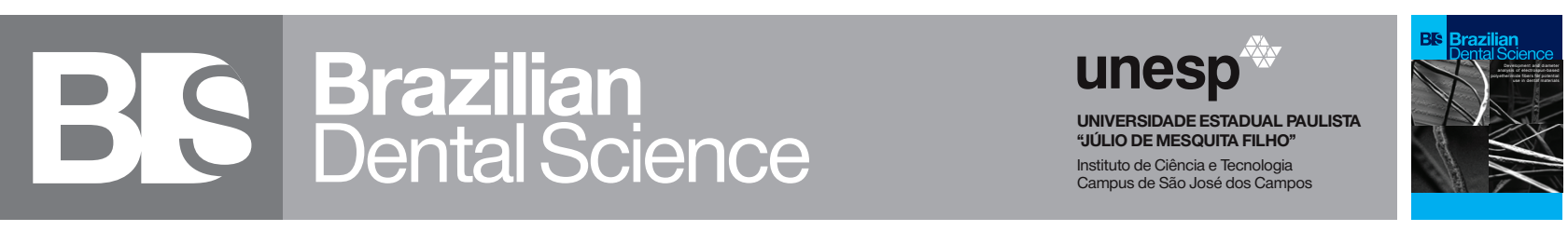

\title{
Clinical evaluation of hydrophobic and hydrophilic pit and fissure sealants among 7-10 year old school children: a split mouth study design
}

Avaliação clínica de fóssulas e físsuras com selantes hidrofóbicos e hidrofílicos entre crianças de 7 a 10 anos de idade: estudo intervencional

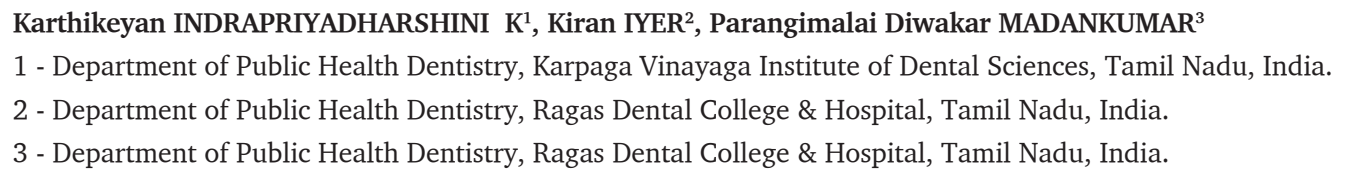

\section{ABSTRACT}

Introduction: The study was done to compare the effectiveness of hydrophobic and hydrophilic pit and fissure sealant retention among 7-10 year old school children. Material and Methods: The present split mouth randomized trial was conducted on the occlusal surfaces of permanent first mandibular molars to compare and assess the retention along with other outcome variables like colour match, marginal discolouration, marginal adaptation, anatomic form, postoperative sensitivity, caries formation and surface roughness properties of Hydrophobic and Hydrophilic pit and fissure sealants at $3^{\text {rd }}$ and $6^{\text {th }}$ month. The data was compiled and analyzed using SPSS software and results were generated. Results: In the present study among the 50 restorations in the hydrophobic pit and fissure sealants (Group I), 48 (96\%) restorations were retained at the end of third month and $45(90 \%)$ were retained at the end of sixth month. Among the 50 restorations in the hydrophilic pit and fissure sealants (Group II), $49(98 \%)$ restorations were retained at the end of third month, and 46(92\%) at the end of sixth month were retained. There was no significant difference in the number of completely retained restorations at the end of six months $(\mathrm{p}=1.00)$ among both the groups. The assessment of all the other outcome variables between both the interventions showed that the difference was

\section{RESUMO}

Introdução: $O$ estudo foi realizado para comparar a eficácia da retenção hidrofóbica e hidrofílica de selante de fóssulas e fissuras entre crianças de 7 a 10 anos de idade escolar. Material e métodos: $O$ presente estudo randomizado de boca dividida foi realizado nas superfícies oclusais dos primeiros molares inferiores permanentes para comparação e avaliação da retenção junto com outras variáveis de resultado, como a cor, descoloração marginal, adaptação marginal, forma anatômica, sensibilidade pósoperatória, formação de cárie e rugosidade de superfícia de selantes hidrofóbicos e hidrofílicos de fóssulas e fissuras no $3^{\circ}$ e $6^{\circ}$ mês de aplicação. Os dados foram analisados usando o software SPSS e os resultados foram obtidos. Resultados: No presente estudo, entre as 50 restaurações com selantes hidrofóbico de fóssulas e fissuras (Grupo I), 48 (96\%) das restaurações ficaram retidas no final do terceiro mês e 45 (90\%) ficaram retidas no final do sexto mês. Entre as 50 restaurações nos selantes de fóssulas e fissuras hidrofílicas (Grupo II), 49 (98\%) restaurações ficaram retidas no final do terceiro mês e 46 (92\%) no final do sexto mês ficaram retidas. Não houve diferença significativa no número de restaurações totalmente retidas ao final de seis meses $(\mathrm{p}=1,00)$ entre os dois grupos. A avaliação de todas as outras variáveis entre as duas intervenções mostrou que a diferença não 
not statistically significant. Conclusion: The study concluded that the hydrophilic pit and fissure sealant was similar to the hydrophobic pit and fissure sealant in terms of retention, colour match, marginal discolouration, marginal adaptation, anatomic form and surface roughness properties with.

\section{KEYWORDS}

Pit and fissure sealants; Moisture tolerant; 7-10 years; School children; Mandibular teeth. foi estatisticamente significativa. Conclusão: $\mathrm{O}$ estudo concluiu que o selante de fóssulas e fissuras hidrofílico era semelhante ao selante de fóssulas e fissuras hidrofóbicas em termos de retenção, combinação de cor, descoloração marginal, adaptação marginal, forma anatômica e rugosidade de superfície.

\section{PALAVRAS-CHAVE}

Selantes de fóssulas e fissuras; Tolerância à umidade; 7 a 10 anos; Crianças em idade escolar; Dentes inferiores.

\section{INTRODUCTION}

P its and fissures are part of occlusal surface anatomy especially those on permanent molars that can trap debris and microorganisms, thereby increasing the risk of developing dental carious lesions [1]. Although occlusal surfaces represent only $12.5 \%$ of the total surfaces of the permanent dentition, they account for almost $50 \%$ of the caries in school children [2]. Pits and fissures are eight times as vulnerable as smooth surface for dental caries [3]. This is because the morphology renders the mechanical means of debridement inaccessible as the average tooth brush bristle $(0.2 \mathrm{~mm})$ is too large to penetrate in most of the fissures which increase caries susceptibility of fissures by many folds [4].

There are signs that the severity of caries in the first molar is increasing in young children, especially in those at high risk of caries. The most appropriate period for the placement of occlusal sealants is soon after eruption of the permanent molars, because recently erupted teeth are less mineralized than those exposed to oral environment for several years. Such teeth have also not undergone the benefits of post eruptive maturation of the enamel and may be thus more prone to acid attack which accelerates the caries formation [5].

However, in spite of the proven efficacy and relative protective effect on application of sealant materials, retention is the main determinant in maintaining a sealant's caries-preventive effect [6].

The conventional resin sealants have high technical sensitivity, hydrophobic in nature and cannot be applied where there is moisture to ensure success [3]. The presence of moisture contamination during the placement of the sealant compromise the quality of adhesion at the sealant enamel interface, which impacts the ongoing resistance to microleakage of microorganisms [7]. Further, concerns have been raised about the possibility of estrogenic chemicals; especially BisGMA may represent additional sources of human exposure and result in potential estrogenecity [8]. Inadequate isolation and saliva contamination during the procedure are the main reasons for failure of fissure sealants [3]. So isolation is imperative for conventional sealants, but it seems to be arduous for erupting teeth especially in young, uncooperative children.

As moisture control in children is a big challenge, and also a key factor for success of the preventive treatment regime, hydrophilic sealants are now made available recently. "It is having good moisture control and devoid of Bis-GMA and Bisphenol A which has the potential to bind with the estrogen receptors at sub toxic concentrations leading to hazardous outcome the development, health and reproductive systems [9]. Considering 
existing challenges in isolation and moisture control, the present study was contemplated as an interventional study to evaluate retention of hydrophilic pit and fissure sealants in comparison with hydrophobic pit and fissure sealants among 7-10 year old school children. The research hypothesis for the present study was there is a difference in the retention among hydrophilic pit and fissure sealants compared to hydrophobic pit and fissure sealants among school children.

\section{MATERIALS AND METHODS}

This was an interventional split mouth designed study to assess and compare the retention of sealants using two different types of materials, namely hydrophobic and hydrophilic pit and fissure sealants in a school based setting over the period of 6 months. A detailed protocol of the study was prepared and approved by the Institution Review Board, Ragas dental college \& hospital, Chennai. The protocol of the study has been registered at the Clinical Trials Registry - India (CTRI) hosted at the ICMR's National Institute of Medical statistics (http://nims-icmr. in) [Reference no: REF/2018/05/019842; Trial registration no: CTRI/2018/05/013871]. Permission to conduct the study was obtained from the school authority and further consent to participate in this study was also obtained from the parents of the study participants in local dialect (Tamil).

The eligibility criteria were set as: Children aged $7-10$ years with fully erupted mandibular permanent first molars bilaterally and children scoring 0 or 1 (Sound tooth surface or First visual change) according to the International Caries Detection and Assessment System [ICDAS II] [10] were included in the study. Children who had enamel defects such as amelogenesis imperfecta, enamel hypoplasia, and dental fluorosis, children suffering from any acute dental infection and children who underwent orthodontic treatment were excluded from the study.
The sample size was calculated with $80 \%$ statistical power, $\alpha=0.05,95 \%$ confidence interval, 10\% margin of error (E) using the nMaster sample size calculator software, version 2.0. After the necessary inputs were given, the sample size estimated was 41 in each group. Hence, anticipating attrition of subjects in the follow up period, the sample size was increased by $10 \%$, a total of 50 subjects were included in the study. Since, the study design was a splitmouth study, 50 subjects were selected to deliver a total of 100 interventions, 50 on either side of mandibular arch. Allocation of type of sealants to the right and left quadrant of the mandibular first molar was done randomly by coin toss method.

\section{Flowchart illustrating the methodology of the study}

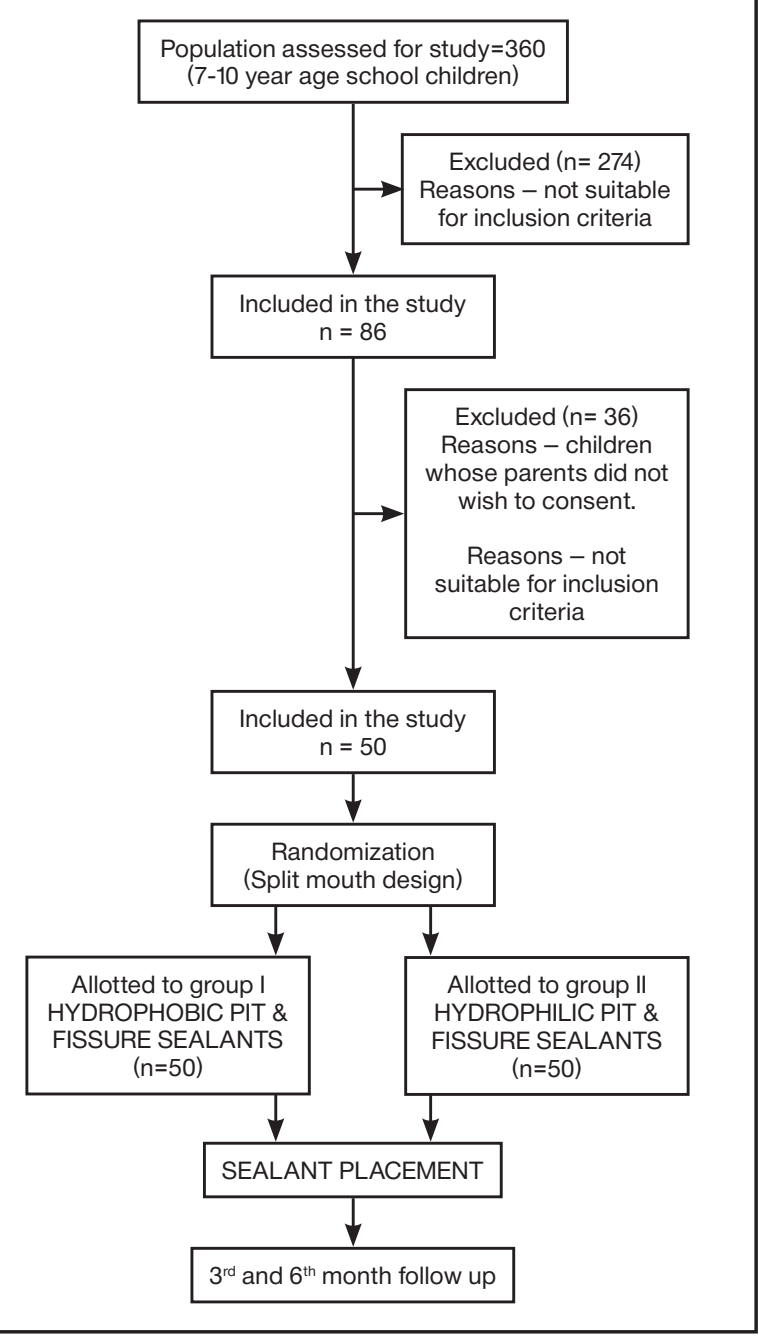




\section{Methodology}

It is a double blind study and clinical procedure was carried out on each subject by placement of one of the interventions on the right mandibular molar on the first day and the other intervention was placed on the left side of mandibular teeth on subsequent day. A single calibrated investigator carried out oral prophylactic procedures for the teeth to be restored by using slurry of pumice and a rotating brush to ensure removal of debris from the fissures and placed all the restorations.

\section{Group I (Hydrophobic):}

Isolation is achieved by using rubber dam and secured with suction. 37\% Ortho phosphoric acid etchant gel was applied for 20 seconds to achieve the" frosty white" appearance, followed by the application of bonding agent and hydrophobic pit and fissure sealant (Helioseal ${ }^{\circledR}$ Assortment, Ivoclarvivadent AG). Material was cured using visible light for 40 seconds (according to the manufacturer's instructions). Inspection of sealant was done for complete coverage or voids and occlusal adjustments were done at the end of the procedure.

\section{Group II (Hydrophilic):}

Isolation was done with prefabricated cotton rolls buccally and lingually along with suction. The same procedural steps were followed like Group I except no bonding agent was applied and followed by the application hydrophilic pit and fissure sealant (Embrace wetbond).

\section{Assessment of outcome variables}

Clinical assessments were made by using USPHS [United States Public Health Service - Modified Ryge Criteria for Direct Clinical Evaluation of Restorations (Cvar and Ryge, 1980) criteria [11] at the end of 3rd month, and 6th month. The retention of the interventions was assessed as a primary outcome and along with it, the other factors such as color match, marginal discoloration, secondary caries, anatomic form, marginal adaptation, post-operative sensitivity, and surface roughness were also assessed as a secondary measures. No attrition in subjects was noted. At the end of each follow up, the subjects were asked if they had any discomfort in the sealed teeth during study period and rectified.

\section{Statistical analysis}

Data obtained were compiled systematically in Microsoft Excel spreadsheet and analyses were performed using a Statistical Package for Social Sciences software (SPSS version 20, USA). Normality was assessed using KolmogorovSmirnov test as each group had 50 interventions and the data was found to be not normally distributed. For all the qualitative data, Chi square test was used for both inter- group and intra group comparisons at the end of 3rd and 6th month. The P value was set for 0.05 and any value equal to or less than was considered to be significant.

\section{RESULTS}

This study was performed on 50 children between 7 to 10 years with a mean age of $7.61 \pm 0.881$ years; out of which, $19(38 \%)$ were boys and $31(62 \%)$ were girls. A total of100 permanent first molar (46 and 36) were evaluated in a split-mouth design. All the 50 subjects who were enrolled in both the groups participated for the entire duration of the study period. No dropouts were reported throughout the study period. 


\section{Evaluation at $3^{\text {rd }}$ month:}

Table I - shows the distribution based on outcome variables of the interventions at the end of the third month. 96\% $(n=48)$ of hydrophobic sealant (Group I) were completely retained when compared to $98 \%(\mathrm{n}=49)$ of hydrophilic sealant (Group II). The difference in the retention between the interventions was not statistically significant at the end of 3 months ( $\mathrm{P}$ $=1.000)$.

No significant difference was noted in terms of color match, marginal discoloration, secondary caries, anatomic form, marginal adaptation, post-operative sensitivity, and surface roughness between the two groups.

\section{Evaluation at $6^{\text {th }}$ month:}

Table II - shows the distribution based on outcome variables of the interventions at the end of the sixth month.

$45(90 \%)$ of hydrophobic group and 46(92\%) hydrophilic group had complete retention, no significant difference was noted at the six month follow-ups between the two sealants $(P=1.000)$. With regard to color match, $100 \%$ of teeth hydrophilic and $98 \%$ of those in hydrophobic group still had acceptable color match at six months $(P=0.741)$. The hydrophobic pit and fissure sealants showed more marginal discolouration (13.4\%) when compared to the hydrophilic pit and fissure sealants $(11.1 \%) .83 \%$ of teeth in hydrophilic group and $78 \%$ in hydrophobic group had acceptable marginal adaptation. Marginal adaptation was not significantly different either between the two groups at any time point $(\mathrm{P}=0.889)$. A total of 10 restorations $(23 \%)$ in hydrophobic and 8 restoration $(17 \%)$ in hydrophilic pit and fissure sealants showed a partial or generalized wear at the end of 6th month. This difference between the interventions was not statistically significant $(P=0.889)$. At the end of six months, the hydrophobic pit and fissure sealants showed $6.6 \%(n=3)$ of surface roughness when compared to hydrophilic pit and fissure sealants which showed 6.5\% $(n=3)$ of surface roughness. These differences between the restorations however were not statistically significant. The present study showed that there was no caries formation in any of the interventions at sixth month. Comparison of all criteria such as retention, color match, marginal discoloration, marginal adaptation, anatomic form, post-operative sensitivity, and surface roughness between both the interventions was not statistically significant during all the followups ( 3rd, and 6th months) (P > 0.05) [table I $\&$ II].

Table I - Assessment of outcome variables in the two groups at $3^{\text {rd }}$ month

\begin{tabular}{|c|c|c|c|c|c|c|}
\hline \multirow[t]{2}{*}{ S. no } & \multirow[t]{2}{*}{$\begin{array}{l}\text { Vari- } \\
\text { ables }\end{array}$} & \multirow[t]{2}{*}{$\begin{array}{l}\text { Scoring } \\
\text { criteria }\end{array}$} & $\begin{array}{l}\text { Group I } \\
\text { (Hydro- } \\
\text { phobic) }\end{array}$ & $\begin{array}{c}\text { Group II } \\
\text { (Hydro- } \\
\text { philic) }\end{array}$ & \multirow{2}{*}{$\begin{array}{c}\text { Chi } \\
\text {-square } \\
\text { value }\end{array}$} & \multirow[t]{2}{*}{ p-Value } \\
\hline & & & $n(\%)$ & $n(\%)$ & & \\
\hline \multirow{2}{*}{1} & \multirow{2}{*}{ Retention } & Retained & $48(96 \%)$ & 49(98\%) & \multirow{2}{*}{0.344} & \multirow{2}{*}{1.000} \\
\hline & & Missed & $02(4 \%)$ & $01(2 \%)$ & & \\
\hline \multirow[b]{2}{*}{2} & \multirow{2}{*}{$\begin{array}{l}\text { Colour } \\
\text { Match }\end{array}$} & Acceptable & $46(96 \%)$ & $47(96 \%)$ & \multirow{2}{*}{0.546} & \multirow{2}{*}{0.988} \\
\hline & & Unacceptable & $02(4 \%)$ & $02(4 \%)$ & & \\
\hline \multirow{2}{*}{3} & \multirow{2}{*}{$\begin{array}{l}\text { Marginal } \\
\text { Discolora- } \\
\text { tion }\end{array}$} & No Discolou- & $42(88 \%)$ & 45(92\%) & \multirow{2}{*}{0.546} & \multirow{2}{*}{0.988} \\
\hline & & Staining & $06(12 \%)$ & $04(8 \%)$ & & \\
\hline \multirow{2}{*}{4} & \multirow{2}{*}{$\begin{array}{c}\text { Marginal } \\
\text { Adaptation }\end{array}$} & Acceptable & $46(96 \%)$ & $47(96 \%)$ & \multirow{2}{*}{0.344} & \multirow{2}{*}{0.982} \\
\hline & & Un acceptable & $02(4 \%)$ & $02(4 \%)$ & & \\
\hline \multirow{2}{*}{5} & \multirow{2}{*}{$\begin{array}{c}\text { Caries } \\
\text { Formation }\end{array}$} & $\begin{array}{l}\text { No evidence of } \\
\text { caries }\end{array}$ & $48(100 \%)$ & $49(100 \%)$ & & \\
\hline & & $\begin{array}{l}\text { Evidence along } \\
\text { margins }\end{array}$ & 0 & $0(\%)$ & & \\
\hline \multirow{2}{*}{6} & \multirow{2}{*}{$\begin{array}{l}\text { Anatomic } \\
\text { Form }\end{array}$} & Acceptable & $46(96 \%)$ & $47(96 \%)$ & \multirow{2}{*}{0.344} & \multirow{2}{*}{0.982} \\
\hline & & Un acceptable & $02(4 \%)$ & $02(4 \%)$ & & \\
\hline \multirow[b]{2}{*}{7} & \multirow{2}{*}{$\begin{array}{l}\text { Post-ope- } \\
\text { rative } \\
\text { Sensitivity }\end{array}$} & Absent & $47(98 \%)$ & $49(100 \%)$ & \multirow[b]{2}{*}{1.010} & \multirow[b]{2}{*}{0.942} \\
\hline & & Present & $01(2 \%)$ & 0 & & \\
\hline \multirow[b]{2}{*}{8} & \multirow{2}{*}{$\begin{array}{l}\text { Surface } \\
\text { Rough- } \\
\text { ness }\end{array}$} & Smooth & $46(96 \%)$ & $46(94 \%)$ & \multirow{2}{*}{0.677} & \multirow{2}{*}{0.980} \\
\hline & & Rough & $02(4 \%)$ & $03(6 \%)$ & & \\
\hline
\end{tabular}


Table II - Assessment of outcome variables in the two groups at $6^{\text {th }}$ month

\begin{tabular}{|c|c|c|c|c|c|c|}
\hline \multirow[t]{2}{*}{ S. no } & \multirow[t]{2}{*}{$\begin{array}{l}\text { Vari- } \\
\text { ables }\end{array}$} & \multirow[t]{2}{*}{$\begin{array}{l}\text { Scoring } \\
\text { criteria }\end{array}$} & $\begin{array}{l}\text { Group I } \\
\text { (Hydro- } \\
\text { phobic) }\end{array}$ & $\begin{array}{c}\text { Group II } \\
\text { (Hydro- } \\
\text { philic) }\end{array}$ & \multirow{2}{*}{$\begin{array}{l}\text { Chi } \\
\text {-square } \\
\text { value }\end{array}$} & \multirow[t]{2}{*}{ p-Value } \\
\hline & & & $n(\%)$ & $n(\%)$ & & \\
\hline \multirow{2}{*}{1} & \multirow{2}{*}{ Retention } & Retained & $45(90 \%)$ & $46(92 \%)$ & \multirow{2}{*}{0.122} & \multirow{2}{*}{1.000} \\
\hline & & Missed & 05(10\%) & $04(8 \%)$ & & \\
\hline \multirow{2}{*}{2} & Colour & Acceptable & $44(98 \%)$ & $46(100 \%)$ & \multirow{2}{*}{1.135} & \multirow{2}{*}{0.741} \\
\hline & Match & Unacceptable & $01(2 \%)$ & 0 & & \\
\hline \multirow[t]{2}{*}{3} & \multirow{2}{*}{$\begin{array}{l}\text { Marginal } \\
\text { Discolora- } \\
\text { tion }\end{array}$} & $\begin{array}{l}\text { No Discolou- } \\
\text { ration }\end{array}$ & $39(87 \%)$ & $41(89 \%)$ & \multirow[t]{2}{*}{1.135} & \multirow[t]{2}{*}{0.741} \\
\hline & & Staining & $06(12 \%)$ & $04(8 \%)$ & & \\
\hline \multirow{2}{*}{4} & \multirow{2}{*}{$\begin{array}{c}\text { Marginal } \\
\text { Adaptation }\end{array}$} & Acceptable & $35(78 \%)$ & $38(83 \%)$ & \multirow{2}{*}{0.352} & \multirow{2}{*}{0.889} \\
\hline & & Un acceptable & 10(22\%) & 08(17\%) & & \\
\hline \multirow{2}{*}{5} & \multirow{2}{*}{$\begin{array}{c}\text { Caries } \\
\text { Formation }\end{array}$} & $\begin{array}{l}\text { No evidence of } \\
\text { caries }\end{array}$ & $45(100 \%)$ & $46(100 \%)$ & \multirow{2}{*}{-} & \\
\hline & & $\begin{array}{l}\text { Evidence along } \\
\text { margins }\end{array}$ & 0 & 0 & & \\
\hline \multirow{2}{*}{6} & \multirow{2}{*}{$\begin{array}{l}\text { Anatomic } \\
\text { Form }\end{array}$} & Acceptable & $35(78 \%)$ & $38(88 \%)$ & \multirow{2}{*}{0.352} & \multirow{2}{*}{0.889} \\
\hline & & Un acceptable & $10(23 \%)$ & 08(17\%) & & \\
\hline \multirow[b]{2}{*}{7} & Post-ope- & Absent & $42(93 \%)$ & $44(96 \%)$ & \multirow{2}{*}{0211} & \multirow[b]{2}{*}{1.000} \\
\hline & $\begin{array}{c}\text { rative } \\
\text { Sensitivity }\end{array}$ & Present & $03(7 \%)$ & $02(4 \%)$ & & \\
\hline \multirow[b]{2}{*}{8} & \multirow{2}{*}{$\begin{array}{c}\text { Surface } \\
\text { Rough- } \\
\text { ness }\end{array}$} & Smooth & $42(93 \%)$ & $43(93 \%)$ & \multirow{2}{*}{0.467} & \multirow{2}{*}{0.834} \\
\hline & & Rough & $03(7 \%)$ & $03(7 \%)$ & & \\
\hline
\end{tabular}

\section{DISCUSSION}

Utilization of an occlusal barrier which isolates the occlusal surface from the surrounding environment in order to impede the onset of caries resulted in the emergence of the sealant systems. Risk of occlusal caries is highest in the first years following eruption of teeth because the enamel is slightly porous and the grooves are full of cellular and organic debris [13]. Hence, fissure sealants with high clinical success rate should be placed as soon as possible after eruption of the teeth [12]. Thus, the present study was undertaken to evaluate and compare the retention properties of two pit and fissure sealants, a hydrophobic and a hydrophilic pit and fissure sealants placed on the occlusal surface of the mandibular permanent first molars among 7 to 10 year children.

The age group of 7- 10 year children were selected for the present study as preventive interventions provides optimal protection of the occlusal surfaces of the first permanent molar teeth, as in a systematic review done by Azarpazhooh A et al (2008) reported that placing sealants within 4 years after eruption seems to be beneficiary [14].

In this study, the retention of the restorations was clinically evaluated using the Modified United States Public Health Service (USPHS) - Ryge criteria for direct clinical evaluation of restoration which assess for retention primarily and other criteria like colour match, cavosurface marginal discolouration, marginal integrity, anatomic contour, caries formation and surface texture. It has to be mentioned cautiously that retention alone cannot be the only indicator of clinical success of a sealant, material properties such as solubility, wear resistance, caries formation are very important in clinical success of restorations and fissure sealants [9].

The results of the present study showed no significant difference in the retention between the hydrophobic (Group I) and hydrophilic (Group II) pit and fissure sealants at the 3rd and 6th months $(P=1.000)$. Therefore this illustrates that although hydrophilic sealant has lower technical sensitivity than hydrophobic sealant they both have similar retention property despite the non-usage of rubber dam during the application of the hydrophilic sealant in contrast to the use of rubber dam for the hydrophobic sealant material. This result substantiates with the fact that hydrophilic sealant when activated, the material is acidic, and, in cured state, it is no longer affected by water and, as a result, cured material has a neutral $\mathrm{pH}$ and very low water solubility which may result in better retention [15].

At the end of six months, the hydrophobic pit and fissure sealants showed more marginal discolouration (13.4\%) when compared to the 
hydrophilic pit and fissure sealants (11.1\%). However, this difference was not statistically significant $(P=0.741)$, as observed in this study, and this finding was ascertained by a study done by Kane et al stated that embrace wet bond shows less polymerization shrinkage than conventional pit and fissure sealants which causes poor marginal seal and marginal discolouration.16

In the current study, change in marginal adaptation was minimal in both groups. The marginal sealing is important for sealant success because penetration of bacteria beneath the sealant might allow caries onset and/ or progression [17]. The hydrophilic pit and fissure sealants showed comparable sealing ability to conventional hydrophobic pit and fissure sealants in the present study. It could be due to low viscosity, water sorption as stated by Prabhakar AR et al [4].

Most of the restorations were found to be continuous with the anatomic form of tooth structure. A total of 10 restorations (22.2\%) in hydrophobic and 8 restoration (17.3\%) in hydrophilic pit and fissure sealants showed a partial or generalized wear at the end of 6th month. The reason mentioned by Fernandes et al in his in vitro study that high polymerization shrinkage, which in turn is related to cavity geometry, quality of a adhesion and the viscoelastic properties of the sealants resulting in breakdown of the enamel sealant micro mechanical union [18].

The two sealants showed similar surface roughness of $6.6 \%(n=3)$, which indicates similar wear resistance. This was corroborates with the findings in an in-vitro study done by Galo et al stated that resin sealants showed a more homogeneous distribution of smaller sized filler particles and bond more effectively with the organic phase susceptible to wear and surface roughness [19].
The present study showed there was no caries formation in any of the interventions which may be due to fluoride uptake by the adjacent enamel. Even in case of loss of sealant, the rest of the sealant often remains in the grooves and served in protective role. Success of a pit and fissure sealant mainly depends on its caries-preventive effect [9].

In the present study, isolation was done using cotton rolls for hydrophilic sealants as stated that absolute isolation is not necessary for the application of this sealants as long as extreme care is taken to avoid salivary contamination of the etched surface to ensure the maximum retention because of Resin Acid - Integrated Network [R.A.I.N.] an improved hydrophilic resin technology [3].

Hence, the study results conclude that the new moisture tolerant hydrophilic pit and fissure sealants was similar to the conventional hydrophobic pit and fissure sealants in terms of retention, colour match, marginal discolouration, marginal adaptation, anatomic form and surface roughness properties. The present study had the following limitations; the study duration for the present study was 6 months; however, efforts should be taken to follow-up for a period of 2 or 3 years for assessing longevity and caries progression. The present study was conducted on a defined population; however, further studies are needed to extrapolate the study findings for generalizability.

\section{CONCLUSION}

Hence, it can be concluded that hydrophilic sealant may be used as effective pit and fissure sealant especially in outreach programmes because of non-usage of rubber dam, ease of application, reduction in operating time. so moisture tolerant sealant make it a suitable sealant for not only clinical setting but also for outreach programmes considering time 
constraints, resources towards isolation will be reduced with similar effectiveness. Longitudinal studies should be conducted to assess the costeffectiveness and the survival rate of each of the intervention.

\section{REFERENCES}

1. Beauchamp J, Caufield PW, Crall JJ, Donly K, Feigal R, Gooch B, et al. Evidence-based clinical recommendations for the use of pit-and-fissure sealants: a report of the American Dental Association Council on Scientific Affairs. J Am Dent Assoc. 2008 Mar;139(3):257-68. doi: 10.14219/jada. archive.2008.0155

2. Mohammed IP, Jaleel BF, Hiremath SS, Manjunath C, AmarahU, Krishnamoorthy A. Comparison of effectiveness of traditional acid etching and of the self-etching agent in sealant retention: A randomized controlled trial. J Indian Assoc Public Health Dent 2016;14:4-9

3. Ratnaditya A, Kumar MG, Avula SS, Jogendra MZ, Kandregula CR, chowdhary Kopuri RK. Clinical evaluation of retention in hydrophobic and hydrophillic pit and fissure sealants A two year follow up study.J Young Pharm 2015;7:1719

4. Prabhakar AR, Murthy SA, Sugandhan S. Comparative evaluation of the length of resin tags, viscosity and microleakage of pit and fissure sealants an in vitro scanning electron microscope study. Contemp Clin Dent2011;2: 324-30.

5. Salama FS, AL-Hammad NS. Marginal seal of sealant and compomer materials with and without enameloplasty. Int J Pediatr Dent. 2002;12:39_ 46.

6. Wendt LK, Koch G, Birkhed D. On the retention and effectiveness of fissure sealant in permanent molars after 15 to 20 years: A cohort study. Community Dent Oral Epidemiol 2001;29(4):302-7.

7. Guclu ZA, Donmez N, Hurt AP, Coleman NJ. Characterisation and microleakage of a new hydrophilic fissure sealant UltraSeal XT ${ }^{\circledR}$ hydro ${ }^{\mathrm{TM}}$. JAppl Oral Sci.2016;24(4):344-51.
8. Azarpazhooh A, Main PA. Is there a risk of harm or toxicity in the placement of pit and fissure sealant materials? A systematic review. J Can Dent Assoc. 2008;74(2): 179-83

9. Askarizadeh N, HeshmatH, Zangeneh N. One-Year clinical success of embrace hydrophilic and helioseal-f hydrophobic sealants in permanent first molars: a clinical trial. J Dent (Tehran). 2017 Mar;14(2):92-9.

10. Ismail Al, Sohn W, Tellez M, Amaya A, Sen A, Hasson H, etal. The International Caries Detection and Assessment System (ICDAS): an integrated system for measuring dental caries. Community Dent Oral Epidemiol 2007;35:170-8.

11. Bayne C, Schmalz G. Reprinting the classic article on USPHS evaluation methods for measuring the clinical research performance of restorative materials. Clin Oral Invest 2005;9:209-214.

12. Kumaran P.Clinical Evaluation of the retention of different pit and fissure sealants: a 1-year study. Int J ClinPediatr Dent 2013;6(3):183-7.

13. Simonsen RJ. Pit and fissure sealant: Review of the literature. Pediatric Dent 2002:24(5):393-14.

14. Azarpazhooh A, Main PA. Pit and fissure sealants in the prevention of dental caries in children and adolescents: A systematic review. J Can Dent Assoc. 2008; 74(2): 179-83.

15. Bhat PK, Konde S, Raj SN, Kumar NC. Moisture tolerant resin based sealant: A boon. ContempClin Dent. 2013 Jul-Sep; 4(3):343-8.

16. Kane B, Karren J, Garcia-Godoy C, Garcia-Godoy F. Sealant adaptation and penetration into occlusal fissures. Am J Dent 2009;22:89-91.

17. Gawali PN, Chaugule VB, PanseAM. Comparison of microleakage and penetration depth between hydrophilic and hydrophobic sealants in primary second molar. Int J ClinPediatr Dent 2016;9(4):291-5.

18. Fernandes KS, Chalakkal P, De Ataide Ide N, Pavaskar R, Fernandes PP, Soni H. A comparison between three different pit and fissure sealants with regard to marginal integrity. J Conserv Dent. 2012;15(2):146-50.

19. Galo $R$, Contente MM, Borsatto MC. Wear of two pit and fissure sealants in contact with primary teeth.Eur J Dent.2014;8(2):241-8.

\section{Indra Priyadharshini} (Corresponding address)

Department of Public Health Dentistry, Karpaga Vinayaga institute of dental sciences, GST road, Chinnakolambakam, Palayanur (PO), Tamil Nadu, India.

Date submitted: 2020 Jul 16

Accept submission: 2020 Sep 29 